\title{
Molecular detection of a haplosporidian parasite in carpet shell clam Ruditapes decussatus from Spain
}

\author{
B. Novoa*, P. Balseiro, A. Figueras \\ Instituto de Investigaciones Marinas, CSIC, Eduardo Cabello 6, 36208 Vigo, Spain
}

\begin{abstract}
A protozoan parasite identified by histology as a haplosporidian was detected in carpet shell clam Ruditapes decussatus from Spain during routine samplings. Analysis based on the sequence of the small subunit ribosomal RNA gene revealed that this organism was related to the haplosporidian group, mainly to Urosporidium. A specific probe was used for in situ hybridization studies to show the specificity of the amplified sequence.
\end{abstract}

KEY WORDS: Haplosporidian $\cdot$ Clam $\cdot$ Ruditapes decussatus

Resale or republication not permitted without written consent of the publisher

\section{INTRODUCTION}

Protozoan infections are of great concern in bivalve aquaculture because some of them infect shellfish species, causing major mortalities. Haplosporidian parasites, mainly Haplosporidium nelsoni and H. costale, have been associated with extensive oyster mortalities in the United States (Andrews 1966, Ford \& Haskin 1982). Haplosporidiosis has also been detected in Europe in flat oysters Ostrea edulis (Van Banning 1977, Azevedo et al. 1999), in Pacific oysters Crassostrea gigas (Renault et al. 2000), in cockles Cerastoderma edule (Carballal et al. 2001) and in clams Ruditapes decussatus L (Azevedo 2001). Perkins (1990, 1991) included 3 genera in the phylum Haplosporidia: Minchinia, Haplosporidium and Urosporidium. Recently, Bonamia ostreae, a notifiable parasite in the European Union, has also been associated with this group (Carnegie et al. 2000, Cochennec et al. 2000).

Azevedo (2001) reported the nomenclature confusion between the 2 genera Minchinia Labbé, 1896 and Haplosporidium Lühe, 1900 included in the family Haplosporidiidae (Azevedo 2001). Haplosporidium tapetis, was first described in clams by Vilela (1951) but was recently named Michinia tapetis (Chagot et al. 1987, Azevedo 2001).

The lack of specific immune responses of marine bivalves makes the efficient diagnosis of potential pathogenic agents an important and effective method to fight against bivalve diseases. In recent years, molecular biology has been critical in the development of diagnostic methods with increased sensitivity and specificity. Since the small subunit ribosomal RNA (18S rRNA or SSU rRNA) gene sequence has specific and conserved areas, it has been one of the most frequently used genes for diagnosis and is widely used for phylogenetic studies.

Several haplosporidians (Haplosporidium nelsoni and $H$. costale) are included in the OIE (Office International des Epizooties) shellfish notifiable diseases list. The characterization of related organisms found in European bivalves is necessary in order to determine if the parasites are, or are not, similar to those considered dangerous for the shellfish industry.

In this study, we report the molecular characterization, based on the SSU rRNA gene, of a haplosporidian found in Galicia (NW Spain) in carpet shell clams Ruditapes decussatus, as well as their phylogenetic relationship with other members of the Haplosporidia.

\section{MATERIALS AND METHODS}

Clams. Carpet shell clams Ruditapes decussatus (30 mm mean long axis length) were collected from 2 locations of Galicia, NW Spain, in February and June 
2002. The animals $(n=184)$ were processed immediately after being received at the laboratory.

Histology. Soft tissues were fixed in Davidson's fixative (Shaw \& Battle 1957) for $24 \mathrm{~h}$, and a transverse section approximately $5 \mathrm{~mm}$ thick including mantle, gonad, digestive gland, gills, kidney, and foot was excised from each clam. Tissue samples were embedded in paraffin, and $5 \mu \mathrm{m}$ sections were stained with hematoxylin-eosin. The histological sections were observed under a light microscope (Nikon).

Amplification of the 18S rRNA gene and sequencing. DNA from carpet shell clams was extracted using DNAzol (Invitrogen) following the recommended protocol.

The 18S rRNA gene was amplified by polymerase chain reaction (PCR) using several pairs of conserved primers derived from known conserved regions of the 18S rRNA gene (Medlin et al. 1988, Figueras et al. 2000, Novoa et al. 2002) (U1S: 5'-AACCTGGTTGATCCTGCCAGT-3'; 336AS: 5'-GCTCCCTCTCCGGAATCGAA-3'; Cas2AS: 5'-ACGGGCGGTGTTCAAAGG-3'; U3S: 5'-GCTACCACATCCAAGGAA-3'; U4AS: 5'-GTCTCGTTCGTTAACGG-3'). PCR was performed in a total volume of $25 \mu$ l containing $1 \mu \mathrm{l}$ $10 \mathrm{mM}$ dNTP mix, $0.125 \mu \mathrm{l}$ Taq polymerase (Roche), $2.5 \mu \mathrm{l}$ Taq $10 \times$ buffer, $1.25 \mu \mathrm{l} 25 \mathrm{mM} \mathrm{MgCl}_{2}, 1.25 \mu \mathrm{l}$ of each primer $(100 \mu \mathrm{M})$ and $1 \mu \mathrm{l}$ of DNA. Following an initial denaturation at $94^{\circ} \mathrm{C}$, reactions were subjected to 40 cycles of initial denaturation at $94^{\circ} \mathrm{C}$ for $1 \mathrm{~min}$, annealing at $50^{\circ} \mathrm{C}$ for $1 \mathrm{~min}$ and extension at $72^{\circ} \mathrm{C}$ for $2 \mathrm{~min}$. A final extension of $10 \mathrm{~min}$ at $72^{\circ} \mathrm{C}$ was also carried out. PCR products were visualized on a $1 \%$ agarose gel stained with ethidium bromide. A 100 bp ladder standard (Amersham Pharmacia) was also included on the gel.

PCR products were cloned directly in the vector pCR 2.1 (Invitrogen) following the standard protocol supplied by the manufacturers (TA Cloning Kit, Invitrogen) and then used to transform competent Escherichia coli TOP10 F'. Screening of clones carrying $18 \mathrm{~S}$ rRNA-coding region fragments was performed by PCR adding the positive colony directly to the PCR mixture reaction using the vector's M13 forward primer. Positive clones were sequenced as described below in order to determine if the gene fragment corresponded to haplosporidians or to other organisms, mainly clams.

PCR products were purified by digestion with the enzymes exonuclease I and shrimp phosphatase (SAP) (Amersham Pharmacia Biotech) for $1 \mathrm{~h}$ at $37^{\circ} \mathrm{C}$. The enzymes were then denatured for $15 \mathrm{~min}$ at $80^{\circ} \mathrm{C}$. The sequencing reactions of purified PCR products were accomplished using ABI Prism BigDye Terminator Cycle Sequencing Ready Reaction according to the manufacturer's directions (Applied Biosystems).
The products resulting from the sequencing reactions were purified by ethanol/ $\mathrm{MgCl}_{2}$ precipitation, and the samples were resuspended in 3 to $5 \mu \mathrm{l}$ of formamide/loading buffer 5:1 (v/v), and denatured at $94^{\circ} \mathrm{C}$ for $3 \mathrm{~min}$. The sequencing was done using an ABI PRISM 377 DNA automatic sequencer (Applied Biosystems). Each product was sequenced at least 3 times.

Phylogenetic analysis. The clam haplosporidian SSU rRNA gene sequence was aligned to other Haplosporidians and to other SSU rRNA gene sequences of protozoan pathogens (Bonamia ostreae AF262995, Bonamia ostreae AF192759, Bonamia sp. AF337563, Mikrocytos roughleyi AF508801, Minchinia teredinis U20319, Minchinia teredinis U20320, Haplosporidium costale AF387122, Haplosporidium costale U20858, Haplosporidium nelsoni AB080597, Haplosporidium nelsoni U19538, Haplosporidium nelsoni X74131, haplosporidian from Haliotis iris AF492442, Urosporidium crescens U47852, Haplosporidium lousiania U47851, Marteilia refringens AJ250699) using the program ClustalW (Thompson et al. 1994).

Evolutionary relationships between the abovedefined rRNA sequences were inferred using the neighbor-joining method (Saitou \& Nei 1987). The accuracy of the resulting tree was measured by bootstrap resampling among 1000 replicates.

Specific PCR and in situ hybridization. In order to confirm that the amplified region corresponded to the haplosporidian detected by histology, a specific probe (103 bp) was generated by PCR with primers 127S (5'ACTCTTTCGGGGGAAGAGAA-3') and 230AS (5'TGCGATCCGAACAATTATCA-3') using digoxigenin dUTP $25 \mathrm{mM}$ in the reaction mix following a modification of the method described by Lipart \& Renault (2002). Briefly, tissue sections ( $7 \mu \mathrm{m}$ thick) placed on silanised slides (Sigma) were dewaxed with xylene and treated with Proteinase K $\left(100 \mu \mathrm{g} \mathrm{ml}^{-1}\right)$. After dehydration with $95 \%$ ethanol and absolute ethanol, tissue sections were air dried and a prehybridization step was carried out with prehybridization buffer $150 \%$ formamide, $10 \%$ dextran sulfate, $4 \times \mathrm{SSC}, 250 \mu \mathrm{g} \mathrm{ml} \mathrm{m}^{-1}$ yeast tRNA) for $30 \mathrm{~min}$ at $42^{\circ} \mathrm{C}$ in a humid chamber. Slides were incubated overnight at $42^{\circ} \mathrm{C}$ with $100 \mu \mathrm{l}$ of the prehybridization buffer containing the specific probe $\left(5 \mathrm{ng}^{-1}\right.$ ). After hybridization, sections were washed with $2 \times \mathrm{SSC}$ and $0.4 \times \mathrm{SSC}$ and the detection of the digoxigenin-labelled probe bound to the parasite was conducted according to the manufacturer's instructions (DIG detection kit, Roche). The slides were finally counter-stained with Bismarck yellow, dehydrated and mounted using Permount. Negative controls included samples incubated without the digoxigenin-labelled probe. Moreover, in situ hybridization was also conducted in tissue sections from mussel Mytilus gallo- 

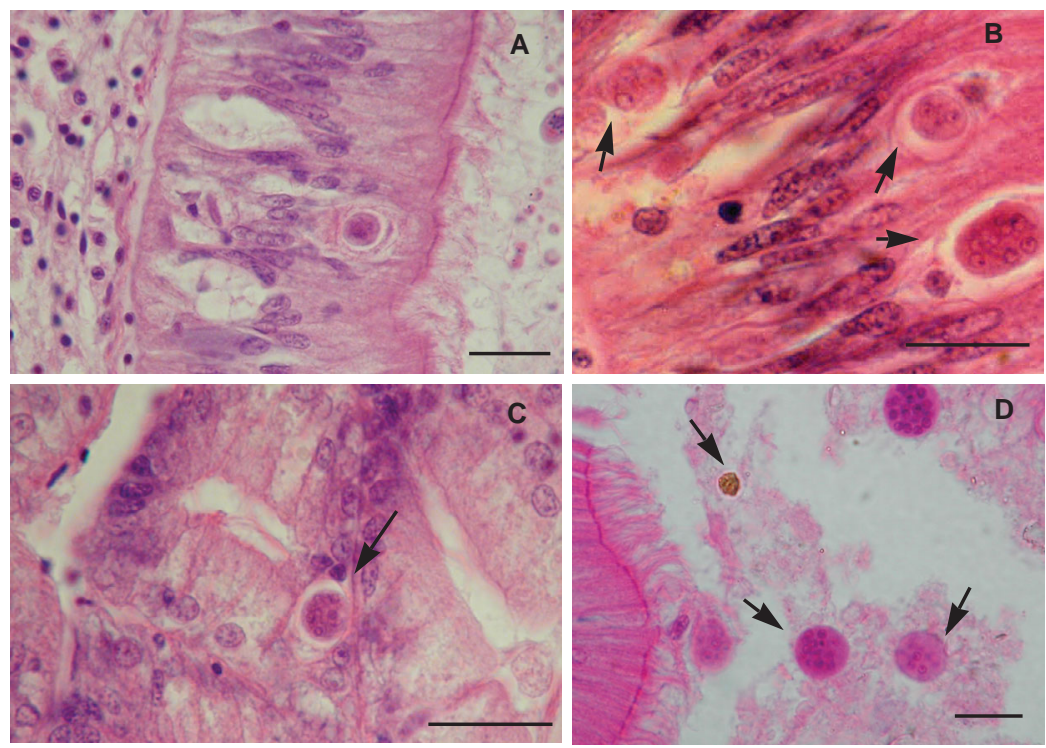

Fig. 1. (A) Haplosporidian plasmodium in the epithelium of the clam stomach. (B) Detail of haplosporidians in the epithelium. (C) Haplosporidian parasite detected in the cells of the digestive tubule. (D) Haplosporidian plasmodia released in the intestine lumen. Arrows show the haplosporidian plasmodia. Scale bars $=30 \mu \mathrm{m}$
After amplification, cloning and subsequent sequencing of the $18 \mathrm{~S}$ rRNA gene, the $1700 \mathrm{bp}$ sequence obtained was compared with public databases using BLAST and confirmed to be similar to the haplosporidians. The GenBank accession number is AY435093.

By using the in situ hybridization technique, the amplified sequence, used as DNA probe, was shown to be specific to this haplosporidian. As can be observed in Fig. 2, the DNA-specific probe applied to infected clam tissue sections yielded strong hybridization signals. This signal was not detected in negative controls or uninfected tissues. Moreover, there was no cross-reactivity with other parasites since the haplosporidian probe did not hybridize with any of the other protozoans tested: Marteilia, Perkinsus and even Bonamia ostreae, which is also related to haplosporidians. provincialis infected with Marteilia sp., from carpet shell clam Ruditapes decussatus infected with Perkinsus atlanticus and from oyster Ostrea edulis infected with Bonamia ostreae.

The specific primers used to generate the specific probe were also used to amplify the $18 \mathrm{~S}$ fragment in 18 infected and uninfected clams with the conditions explained above in order to compare the results with the histology.

\section{RESULTS}

A protozoan parasite morphologically identified as being a haplosporidian was detected by histology in carpet shell clams from 2 locations in Galicia with high prevalence. Site A showed 36 and $48 \%$ in February and June 2002, and Site B, 52.4 and $71.4 \%$ in February and June 2002. At both sites, an increase in the percentage of clams infected by haplosporidian parasites was observed from February to June. Clams did not experience unusual mortalities during this period. The plasmodium stage of the parasite was found mainly in the digestive epithelium, which could be considered the target organ (Fig. 1), but it could also be detected in a few cases in the connective tissue and in the digestive gland. No histopathological features associated with the presence of this protozoan parasite were detected. Spores were never found in affected clams, which did not facilitate the identification of the parasite following the established morphological criteria (Burreson 2001).

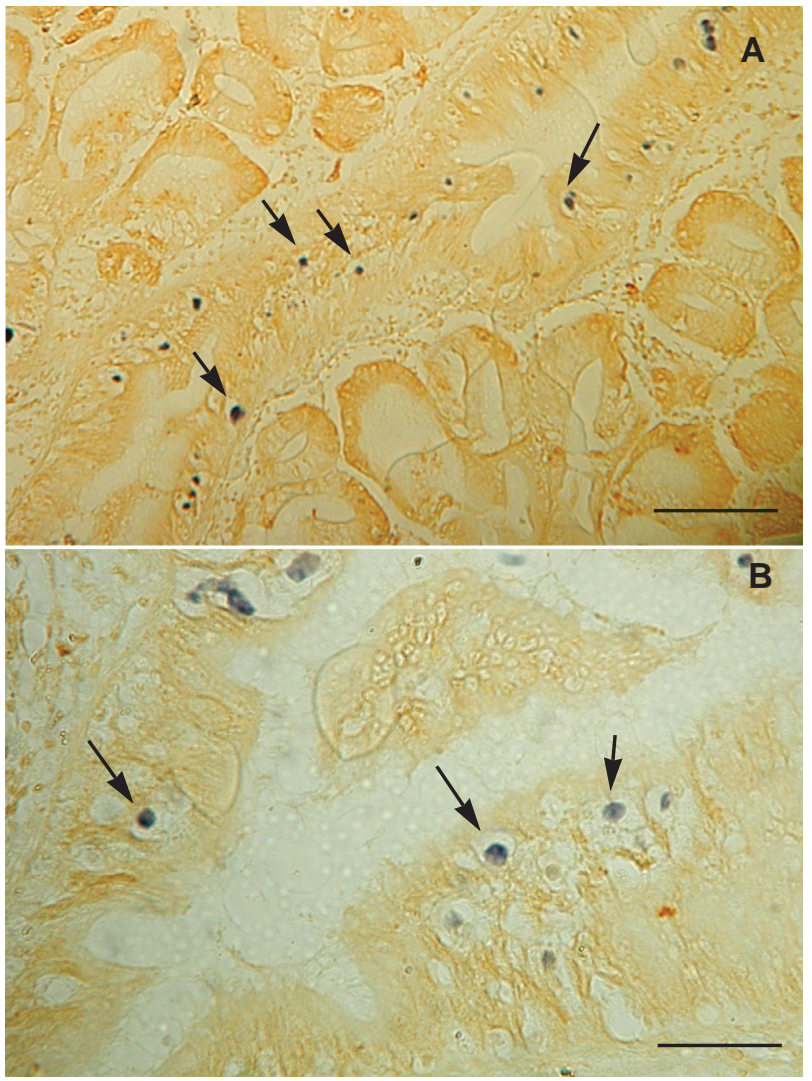

Fig. 2. Haplosporidian plasmodia (arrows) identified by the in situ hybridization technique. (A) General view of the digestive gland. (B) Detail showing the haplosporidian plasmodia in the digestive epithelium. Scale bars $=50 \mu \mathrm{m}$ 


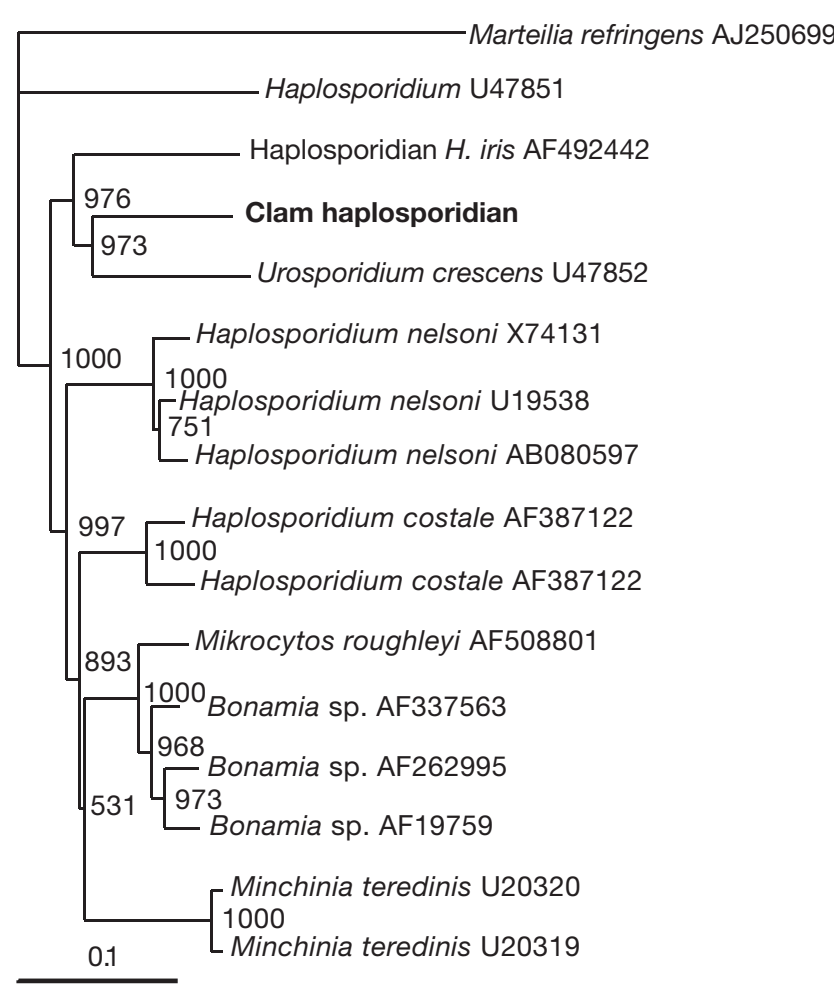

Fig. 3. Phylogenetic tree with GenBank accession numbers of clam haplosporidian parasite and other related pathogens derived from the 18S rRNA gene. Numbers at nodes represent the level of bootstrap value support based on 1000 replicates $(<75 \%$ not shown). Bar $=1 \%$ sequence divergence

The PCR conducted on clam tissues using the primers 127 to 230 produced specific amplification of the clam haplosporidian. When PCR results were compared with those of histology, differences were found between the 2 methods only in 2 samples. However, the percentage of positive cases was the same using both techniques $(72.2 \%)$.

The phylogenetic studies comparing a common $18 \mathrm{~S}$ fragment among all the haplosporidians found in GenBank suggests that the clam protozoan, although morphologically similar to haplosporidians, is closely related to Urosporidium crescens, a hyperparasite of a trematode found in the American blue crab Callinectes sapidus (Perkins 1971), and the recent isolate from Haliotis iris (Reece \& Stokes 2003). Minchinia species are in a different branch (Fig. 3).

\section{DISCUSSION}

In Galicia, NW Spain, haplosporidian parasites have been described in clams Ruditapes decussatus (Figueras et al. 1992), in cockles Cerastoderma edule (Carballal et al. 2001) and also in flat oysters Ostrea edulis L. (Azevedo et al. 1999). In the latter species, by a study of the spore morphology, Azevedo et al. (1999) named the parasite Haplosporidium armoricarum. In Portugal, haplosporidians found in clams were identified as Minchinia tapetis by Azevedo (2001) after ultrastructural characterization of spores allowed him to assign this parasite to the Minchinia genus. Spore ornamentation, studied by scanning and transmission electron microscopy, is used as a key character for species differentiation and genus assignment in the phylum Haplosporidia (Azevedo 2001, Burreson 2001). It is difficult to know if the clam haplosporidian parasite from Portugal and Spain are the same, since in infected clams from Galicia it was not possible to find sporulation stages in the clam gills (Figueras et al. 1992, present study).

Molecular techniques have been used to clarify the taxonomy of haplosporidians. Based on 18S rRNA gene sequences, Siddall et al. (1995) and Flores et al. (1996) situated the phylum Haplosporidia as a monophyletic group within the Alveolata. However, Cavalier-Smith \& Chao (2003) reported that haplosporidian and paramyxid parasites of shellfish, including the Marteilia genus, group together, comprising the Ascetosporea, and were not 2 separate phyla, but part of the phylum Cercozoa.

In our study, the clam haplosporidian seems to be more closely related to the Urosporidium group and is different from Minchinia teredinis and the Haplosporidium genus; $M$. teredinis belongs to the same genus as Minchinia tapetis, thought to infect clams, and Haplosporidium is the genus to which H. nelsoni and $H$. costale (both notifiable pathogens for shellfish) belong. Although the organism examined in this study looks very much like a 'traditional' Haplosporidium, the phylogenetic analysis of the sequence relates it to Urosporidium and not to the Haplosporidium or Minchinia groups.

In situ hybridization studies demonstrated that there was no cross-reactivity with other bivalve protozoan parasites present in the same area. Interestingly, the haplosporidian probe did not hybridize with Bonamia ostreae although it also belongs to the haplosporidian group.

Until now, the parasite does not seem to have caused or be related to any clam mortalities. The selected sites were part of a routine sampling of clams. However, Carballal et al. (2001) suggested that haplosporidians detected in other bivalve species cultured in the same areas, such as cockles, could represent a problem, since in high intensity infections, the cockle connective tissue appeared destroyed and full of spores. The molecular approaches will help to clarify if these 2 parasites are or are not the same, and what is the role of clams in the haplosporidian life cycle. 
Acknowledgements. This work was supported by the project PGIDT 01MAR 40203PR funded by Xunta de Galicia, Spain. The authors thank to Dorita Pose, Eva Amorín and Maria Pazos for their technical assistance.

\section{LITERATURE CITED}

Andrews JD (1966) Oyster mortality studies in Virginia. V. Epizootiology of MSX, a protistan pathogen of oyster. Ecology 47:19-31

Azevedo C (2001) Ultrastructural description of the spore maturation stages of the clam parasite Minchinia tapetis (Vilela, 1951) (Haplosporida: Haplosporidiidae). Syst Parasitol 49:189-194

Azevedo C, Montes J, Corral L (1999) A revised description of Haplosporidium armoricanum, parasite of Ostrea edulis L. from Galicia, northwestern Spain, with special reference to the spore-wall filaments. Parasitol Res 85:977-983

Burreson EM (2001) Spore ornamentation of Haplosporidium pickfordi Barrow, 1961 (Haplosporidia), a parasite of freshwater snails in Michigan, USA. J Eukaryot Microbiol 48:622-626

Carballal MJ, Iglesias D, Santamarina J, Ferro-Soto B, Villalba A (2001) Parasites and pathologic conditions of the cockle Cerastoderma edule populations of the coast of Galicia (NW Spain). J Invertebr Pathol 78:87-97

Carnegie RB, Barber BJ, Culloty SC, Figueras A, Distel DL (2000) Development of a PCR assay for detection of the oyster pathogen Bonamia ostreae and support for its inclusion in the Haplosporidia. Dis Aquat Org 42:199-206

Cavalier-Smith T, Chao EE (2003) Phylogeny of choanozoa, apusozoa, and other protozoa and early eukaryote megaevolution. J Mol Evol 56:540-563

Chagot D, Bachère E, Ruano F, Comps M, Grizel H (1987) Ultrastructural study of sporulated instars of a haplosporidian parasitizing the clam Ruditapes decussatus. Aquaculture 67:262-263

Cochennec N, Le Roux F, Berthe F, Gerard A (2000) Detection of Bonamia ostreae based on small subunit ribosomal probe. J Invertebr Pathol 76:26-32

Figueras A, Robledo JA, Novoa B (1992) Occurrence of Haplosporidian and Perkinsus-like infections in carpet-shell clams, Ruditapes decussatus (Linnaeus, 1758), of the Ría de Vigo (Galicia, NW Spain). J Shellfish Res 11:377-384

Figueras A, Lorenzo G, Ordás MC, Gouy M, Novoa B (2000) Sequence of the small subunit ribosomal RNA gene of Perkinsus atlanticus-like isolated from carpet shell clam in Galicia, Spain. Mar Biotechnol 2:419-428

Flores BS, Siddall ME, Burreson EM (1996) Phylogeny of the Haplosporidia (Eukaryota: Alveolata) based on small subunit ribosomal RNA gene sequence. J Parasitol 82:616-623

Editorial responsibility: Carey Cunningham, Aberdeen, UK
Ford SE, Haskin HH (1982) History and epizootiology of Haplosporidium nelsoni (MSX), an oyster pathogen in Delaware Bay, 1957-1980. J Invertebr Pathol 40: 118-141

Lipart C, Renault T (2002) Herpes-like virus detection in infected Crassostrea gigas spat using DIG-labelled probes. J Virol Methods 101:1-10

Medlin L, Elwood HL, Stickel S, Sogin ML (1988) The characterization of enzymatically amplified eukaryotic 16S-like rRNA-coding regions. Gene 71:491-499

Novoa B, Ordás C, Figueras A (2002) Hypnospores detected by RFTM in clam (Ruditapes decussatus) tissues belong to 2 different organisms, Perkinsus atlanticus and a Perkinsus-like organisms. Aquaculture 209:11-18

Perkins FO (1971) Sporulation in the trematode hyperparasite Urosporidium crescens De Turk 1940 (Haplosporida: Haplosporiidae) an electron microscopy study. J Parasitol 57:9-23

Perkins FO (1990) Phylum Haplosporidia. In: Margulis L, Corliss JL, Melkonian M, Chapman DJ (eds) Handbook of protoctista. Jones \& Bartlett, Boston, MA, p 19-29

Perkins FO (1991) 'Sporozoa': Apicomplexa, Microsporidia, Haplosporidia, Paramyxea, Myxosporidia and Actinosporidia. In: Harrison FW, Corliss JO (eds) Microscopic anatomy of invertebrates, Vol 1. Protozoa. Wiley-Liss, New York, p 261-331

Reece KS, Stokes NA (2003) Molecular analysis of a haplosporidian parasite from cultured New Zealand abalone Haliotis iris. Dis Aquat Org 53:61-66

Renault $\mathrm{T}$, Stokes NA, Chollet $\mathrm{B}$, Cochennec N, Berthe $\mathrm{F}$, Gerard A, Burreson EM (2000) Haplosporidiosis in the Pacific oyster Crassostrea gigas from the French Atlantic coast. Dis Aquat Org 42:207-214

Saitou N, Nei M (1987) The neighbor-joining method: a new method for reconstructing phylogenetic trees. Mol Biol Evol 4:406-425

Shaw BL, Battle H (1957) The gross microscopic anatomy of the digestive tract of Crassostrea virginica (Gmelin). Can J Zool 35:325-346

Siddall ME, Stokes NA, Burreson EM (1995) Molecular phylogenetic evidence that the phylum Haplosporidia has an alveolate ancestry. Mol Biol Evol 12:573-581

Thompson JD, Higgins DG, Gibson TJ (1994) CLUSTAL W: improving the sensitivity of progressive multiple sequence alignment through sequence weighting, position-specific gap penalties and weight matrix choice. Nucleic Acids Res 22:4673-4680

Van Banning P (1977) Minchinia armoricana sp. Nov. (Haplosporida), a parasite of the European flat oyster, Ostrea edulis. J Invertebr Pathol 30:199-206

Vilela H (1951) Sporozoaires parasites de la palourde, Tapes decussatus (L). Rev Fac Ciênc Univ Lisb 1:379-386

Submitted: December 8, 2003; Accepted: June 2, 2004

Proofs received from author(s): September 16, 2004 